\title{
Identification of symbiosis-specific c-type cytochromes and a putative oxidase in bacteroids of Rhizobium leguminosarum biovar viciae
}

\author{
Carmen Vargas, ${ }^{1}+$ Guanghui Wu, ${ }^{2}$ Maria-Jesus Delgado, ${ }^{1}$ Robert K. \\ Poole ${ }^{2}$ and J. Allan Downie'
}

\begin{abstract}
Author for correspondence: J. Allan Downie. Tel: +44 1603 452571. Fax: + 441603456844.
\end{abstract}
e-mail: Downie@bbsrc.ac.uk

\footnotetext{
1 John Innes Centre, Norwich, NR4 7UH, UK

2 Division of Life Sciences, King's College London, London W8 7AH, UK
}

\begin{abstract}
Covalently bound haem proteins and cytochromes were analysed in Rhizobium leguminosarum biovar viciae free-living cells and nitrogen-fixing bacteroids isolated from pea nodules. Increased levels of spectroscopically detectable cytochrome $c$ in bacteroids were correlated with the appearance of two proteins of $M_{\mathrm{r}} \mathbf{3 0 0 0 0}$ and 28000 that contained covalently bound haem. Conversely, bacteroids had undetectable levels of a periplasmic cytochrome $c$ of $M_{r} 14000$ that is normally present in free-living bacteria. Difference spectra confirmed that the terminal oxidases, cytochromes $\mathrm{aa}_{3}$ and $d$, were absent, and photodissociation spectra revealed novel components that may be due to a bacteroid terminal oxidase.
\end{abstract}

Keywords: Rhizobium, cytochromes, nitrogen-fixation, bacteroids, haem

\section{INTRODUCTION}

When bacteria of the genera Rbizobium, Bradyrbizobium and Azorbizobium (rhizobia) develop into nitrogen-fixing bacteroids in the root nodules of legumes, several genes involved in symbiotic nitrogen fixation are induced. Some of these genes are involved in the formation of the enzymes required for the reduction of nitrogen, while others are involved in the high level of bacteroid metabolism required to provide the energy to drive the nitrogen fixation process. The nitrogenase is very oxygenlabile and within legume nodules the oxygen concentration is maintained at a low level, estimated to be in the range 5-30 nM (Appleby, 1984). At such low oxygen concentrations, plant-made leghaemoglobin, which has a high affinity for oxygen and an appropriate oxygen 'off' rate, facilitates oxygen diffusion. To optimize respiration in this low-oxygen environment, a novel branch of the electron transport pathway encoded by the fixNOQP genes is induced in bacteroids of Bradyrbizobium japonicum (Preisig et al., 1993), Azorbizobium caulinodans (Mandon et al., 1994), Rbizobium meliloti (Kahn et al., 1993) and Rhizobium leguminosarum (Schluter et al., 1993). It is proposed that fixO and $f \times P$ encode two proteins with characteristics similar to $c$-type cytochromes and that fixN

†Present address: Departamento Microbiologia y Parasitologia, Facultad de Farmacia, Universidad de Sevilla, 41012 Sevilla, Spain. encodes a haem-binding terminal oxidase that resembles subunit I of $\mathrm{Cu}$-containing terminal oxidases (Preisig et al., 1993).

When the fix NOQP genes are induced, some cytochromes decrease in amount in bacteroids. Thus, in B. japonicum and $R$. leguminosarum, cytochrome $a a_{3}$ is absent from bacteroids whereas it is a normal component of bacteria grown in aerobic culture (Appleby, 1969a, b). When cultured in the presence of normal or lowered levels of oxygen, R. leguminosarum cells were reported (Kretovich et al., 1973) to show little alteration in the level of cytochrome $a a_{3}$ but showed significantly increased levels of cytochrome $d$ when oxygen became limiting. Neither of these two oxidases was found in bacteroids (Kretovich $e t$ al., 1973). We have extended the characterization of haem proteins present in $R$. leguminosarum bacteroids by identifying two symbiosis-specific $c$-type cytochromes. As well as confirming the lack of cytochromes $a a_{3}$ and $d$, we have used low-temperature photodissociation methods to reveal a ligand-reactive haem protein that is a candidate for the high-affinity symbiosis-specific terminal oxidase in $R$. leguminosarum biovar viciae.

\section{METHODS}

Microbiological techniques. R. leguminosarum bv. viciae strain 8401/pRL1JI (Downie et al., 1983) was used throughout. Bacteria were cultured in Y minimal medium (Sherwood, 1970) 
containing succinate $(10 \mathrm{mM})$ and glutamate $(10 \mathrm{mM})$ as carbon and nitrogen sources. Flasks (2 l l) containing $500 \mathrm{ml}$ medium were inoculated with $10 \mathrm{ml}$ of a starter culture and shaken for $3 \mathrm{~d}$ at $30{ }^{\circ} \mathrm{C}$ in an orbital shaker. The cells were harvested by centrifugation, then washed once in $20 \mathrm{mM} \mathrm{KH}_{2} \mathrm{PO}_{4}$ buffer, $\mathrm{pH}$ 7.

For production of bacteroids, peas grown in sterilized Erlenmeyer flasks containing $200 \mathrm{ml}$ Fahraeus medium with $0.5 \%$ agar (Beynon et al., 1980) were inoculated with $R$. leguminosarum bv, viciae and grown for $24 \mathrm{~d}$. The nodules were harvested and bacteroids were isolated by sucrose-densitygradient centrifugation as described by Brewin et al. (1985).

Cell fractionation, protein gel electrophoresis and haem staining. R. leguminosarum cells from a $300 \mathrm{ml}$ culture grown in $\mathrm{Y}$-succinate medium or bacteroids isolated from $5 \mathrm{~g}$ nodules were resuspended in $3 \mathrm{ml} 100 \mathrm{mM}$ potassium phosphate buffer ( $\mathrm{pH} 7 \cdot 0$ ) containing $100 \mu \mathrm{M}$ 4-amidinophenylmethanesulfonyl fluoride and DNase I $\left(20 \mu \mathrm{g} \mathrm{ml}^{-1}\right)$. Cells were disrupted using a French pressure cell (SLM Aminco). The cell extract was centrifuged at $20000 \mathrm{~g}$ for $20 \mathrm{~min}$ to remove unbroken cells and the supernatant was then centrifuged at $140000 \mathrm{~g}$ for $2 \mathrm{~h}$. The membrane pellet was resuspended in $2 \mathrm{ml}$ of the same buffer, centrifuged at $140000 \mathrm{~g}$ for $2 \mathrm{~h}$ and then resuspended in $100 \mu \mathrm{l}$ buffer. 'The supernatant 'soluble fraction' from the first centrifugation at $140000 \mathrm{~g}$ was concentrated using a Centricon10 filter. Protein concentrations were estimated by the method of Bradford (1976) using BSA as standard. Membrane and soluble fractions were suspended in loading buffer $(124 \mathrm{mM}$ Tris, $\mathrm{pH} 7 \cdot 0,20 \%, \mathrm{v} / \mathrm{v}$, glycerol, $4 \cdot 6 \%, \mathrm{w} / \mathrm{v}, \mathrm{SDS})$, incubated at $20{ }^{\circ} \mathrm{C}$ for $10 \mathrm{~min}$, separated by SDS-PAGE and transferred to a nitrocellulose filter following the procedures described by Bradley et al. (1988). Proteins containing covalently bound haem were stained by chemiluminescence as described by Vargas et al. (1993) using an Amersham enhanced chemiluminescence kit.

Potential contamination of the bacteroid extract by mitochondria was assayed using antibody to pea lipoamide dehydrogenase, a mitochondrial-specific marker (Turner et al., 1992). Proteins separated by SDS-PAGE and transferred to a nitrocellulose filter were incubated with a 1:500 dilution of antiserum under the conditions described by Bradley et al. (1988). Binding of the antibody was visualized using rabbit anti-rat IgG conjugated to alkaline phosphatase (Sigma), used at a 1:2000 dilution, following the staining conditions described by Bradley et al. (1988). As a positive control, $1 \mathrm{~g}$ uninoculated pea root tips was homogenized in a mortar and pestle in $1 \mathrm{ml}$ extraction buffer $(50 \mathrm{mM}$ Tris $/ \mathrm{HCl}, \mathrm{pH} 7.5,10 \mathrm{mM}$ DTT, 0.5 M sucrose, $5 \%, \mathrm{w} / \mathrm{v}$, insoluble polyvinylpyrrolidone and $5 \mathrm{mM} p$-aminobenzamidine). The homogenate was filtered through Miracloth (Calbiochem) before solubilization in gel loading buffer. Relative $M_{\mathrm{r}}$ values of proteins were estimated using the 'Rainbow' $M_{\mathrm{r}}$ markers from Amersham.

Measurements of spectra. Spectra were measured with a Johnson Foundation SDB3 dual wavelength spectrophotometer (Williams \& Poole, 1987) using a reference wavelength of $575 \mathrm{~nm}$ and a spectral band width of $4 \mathrm{~nm}$. For reduced minus oxidized spectra, cells resuspended in buffer were reduced with a few grains of dithionite or oxidized with a few grains of ammonium persulphate. For the reduced-plus-CO minus reduced spectra, the dithionite-reduced cells were bubbled for $1 \mathrm{~min}$ with CO.

For the photodissociation spectra, dithionite-reduced cells or cells reduced in the presence of succinate $(2 \mathrm{mM})$ and malate $(2 \mathrm{mM})$ were bubbled with $\mathrm{CO}$ for $1 \mathrm{~min}$, cooled to $-20^{\circ} \mathrm{C}$ for $5 \mathrm{~min}$ and then cooled to $-78^{\circ} \mathrm{C}$ for $10 \mathrm{~min}$ in the dark before equilibration at $-100^{\circ} \mathrm{C}$ in the sample compartment (Poole et al., 1983, 1994) using the cryostat illustrated by Jones \& Poole (1985). The sample was scanned twice to generate a baseline (reduced-plus-CO spectrum minus reduced-plus-CO spectrum) and then photolysed using a focused $200 \mathrm{~W}$ light beam. The spectra shown are the differences between the CO-dissociated sample and the reduced-plus-CO sample.

\section{RESULTS AND DISCUSSION}

\section{Novel covalently bound haem proteins in bacteroids}

Cytochromes of the $c$-type have a covalently bound haem group that is retained during SDS-PAGE. These haem groups have an intrinsic peroxidase activity that can be used to identify the proteins after gel separation. $R$. leguminosarum bv. viciae cells lysed using a French pressure cell were fractionated into soluble and membrane fractions and the proteins separated by SDS-PAGE. Covalently bound haem proteins were visualized using a haem stain.

In the membrane fractions from free-living cells, two stained bands of $M_{\mathrm{r}} 31000$ and $M_{\mathrm{r}} 23000$ were detected (Fig. 1a, lane 1). The larger protein is similar in size to cytochrome $c_{1}$ from B. japonicum (Thöny-Meyer et al., 1989), and a mutation in the R. leguminosarum bv. viciae cytochrome $c_{1}$ gene abolishes the formation of this protein (unpublished observations). The smaller band is similar in size to the membrane-bound $c$-type cytochrome $\mathrm{CycM}$ $\left(M_{\mathrm{r}} 20000\right)$ described by Bott et al. (1991) in B. japonicum.

In the membrane fraction of bacteroids the total amount of haem-stained proteins was considerably higher than that seen with membranes from free-living cells (Fig. 1a, lanes 1 and 5). The increased level was principally due to the appearance of two strongly stained bands at estimated $M_{\mathrm{r}}$ values of 30000 and 28000 . To resolve these components it was necessary to decrease the amount of protein loaded on the gel (Fig. 1a, lanes 2, 3 and 4). In addition to these two bands, there appears to be a more weakly stained band at about $M_{\mathrm{r}} 31000$ (arrowed), corresponding in size with the cytochrome $c_{1}$ component found in membranes from free-living cells (Fig. 1a, lanes 3 and 4). At about $M_{\mathrm{r}} 23000$ two bands were detected (Fig. 1a, lanes 4 and 5); presumably one of these corresponds to the component of $M_{\mathbf{r}} 23000$ found in membranes from free-living cells. It is not possible to distinguish if the other band in this range is a novel component or a degradation product of one of the other haem proteins; indeed other weakly staining bands that might be degradation products can be seen at the higher levels of protein loading (Fig. 1a, lane 5).

In the soluble fraction of free-living cells (Fig. 1b, lane 1) a stained protein of about $M_{\mathrm{r}} 14000$ is present and this was shown previously to be a periplasmic protein (Vargas et al., 1994). This component was not detected in the soluble fraction from bacteroids (Fig. 1b, lane 2). Thus it appears that the expression of this cytochrome, like that of cytochrome $a a_{3}$ (see below), is greatly reduced in bacteroids. This contrasts with the significantly increased level of absorption of $c$-type cytochromes (see below), implying that the increase in absorption is due to the novel membrane-bound components. 
(a)

1

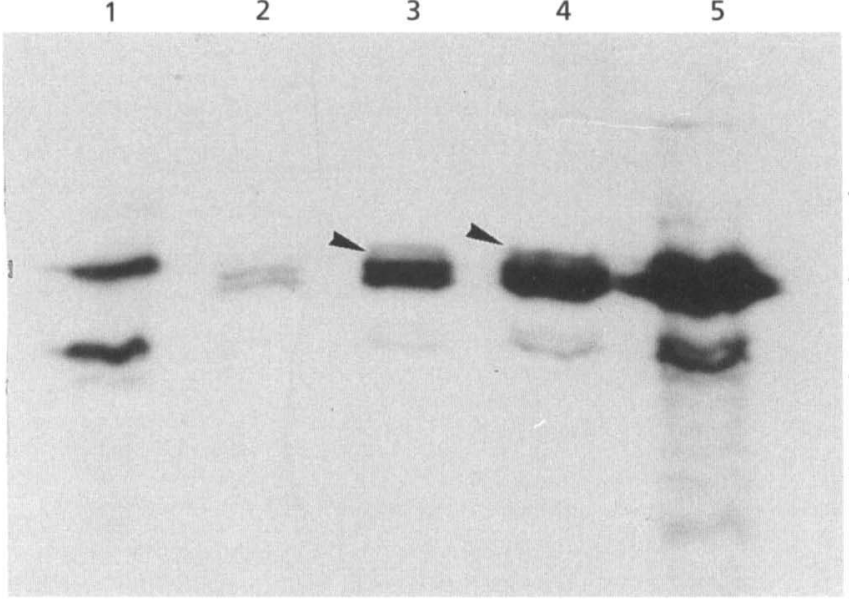

(b)

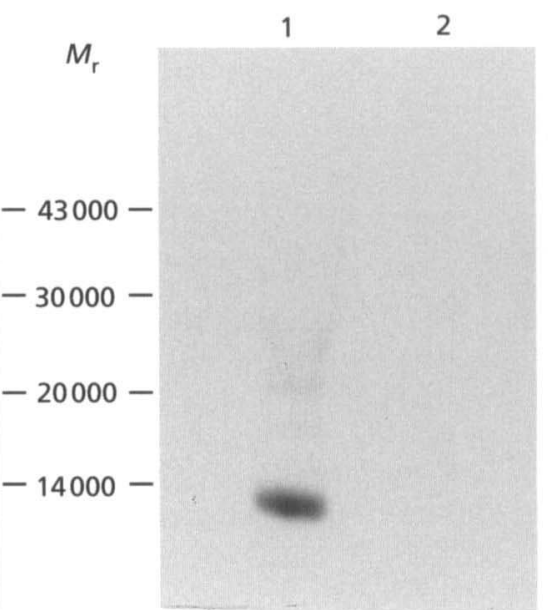

Fig. 1. Covalently bound haem proteins in membrane (a) and soluble (b) fractions from cultured cells and bacteroids of $R$. leguminosarum strain A34. Proteins were separated by SDS-PAGE and stained for the presence of covalently bound haem as described previously by Vargas et al. (1993). In (a) lane 1 contains $50 \mu \mathrm{g}$ protein from the membrane fraction of freeliving cells and lanes $2,3,4$ and 5 contain, respectively, $2.5 \mu \mathrm{g}, 6 \mu \mathrm{g}, 12 \mu \mathrm{g}$ and $50 \mu \mathrm{g}$ proteins from the membrane fraction of bacteroids isolated from pea nodules. In (b) lanes 1 and 2 each contain $50 \mu$ protein from the soluble fraction of free-living cells and bacteroids, respectively. The positions of migration of $M_{\mathrm{r}}$ markers are indicated. The arrows indicate the band in bacteroids attributed to cytochrome $c_{1}$.

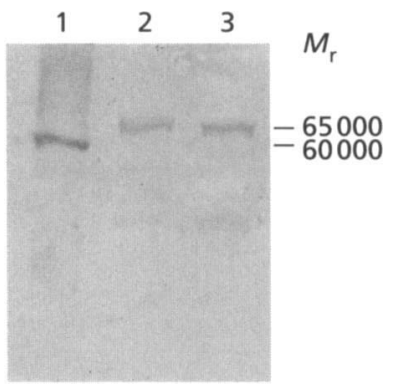

Fig. 2. Immunostaining of bacteroids with antibody to pea lipoamide dehydrogenase. Protein extracts $(10 \mu \mathrm{g}$ protein) from uninoculated pea roots (lane 1), bacteroids (lane 2) and cultured bacteria (lane 3) were separated by SDS-PAGE, transferred to nitrocellulose and stained with antibody to pea lipoamide dehydrogenase, which recognizes a pea mitochondrial protein of $M_{r} 60000$ (Turner et al., 1992). The estimated sizes of stained bands are indicated.

We considered the possibility that the novel components in the bacteroid fraction might be due to contamination with plant mitochondria from nodule cells. However, when an immunoblot of bacteroid proteins and of root extract was probed with antibody to pea lipoamide dehydrogenase (a mitochondrial-specific marker) (Turner et al., 1992), there was strong cross-reactivity with a protein of $M_{\mathrm{r}} 60000$ in root extract (Fig. 2, lane 1) but no reaction at the corresponding size in the bacteroid fraction (Fig. 2, lane 2). Interestingly, a component of $M_{\mathrm{r}} 65000$ was stained in the bacteroid extract and a protein of the same size was detected in an extract of cultured bacteria (Fig. 2, lanes 2 and 3), indicating that the antiserum to pea lipoamide dehydrogenase recognizes a bacterial protein; this component may correspond to the $R$. leguminosarum lipoamide dehydrogenase. The absence of the pea lipoamide dehydrogenase in the bacteroid extract excludes significant mitochondrial contamination of the bacteroids, showing that the novel haem-staining bands are indeed bacteroid components.

Preisig et al. (1993) predicted that the $f i x O$ and $f \times P$ genes encode membrane-anchored $c$-type cytochromes. The fixNOQP operon is conserved in many (possibly all) rhizobia and is induced in bacteroids during nitrogen fixation. The predicted $M_{\mathrm{r}}$ values of the FixO and FixP apoproteins are 27352 and 31023 , respectively, in $B$. japonicum (Preisig et al., 1993) and very similar in $A$. caulinodans (Mandon et al., 1994). The additional haemstaining proteins identified here at $M_{\mathrm{r}} 28000$ and $M_{\mathrm{r}}$ 30000 in bacteroids correspond in size to those predicted for the $f i x O$ and $f x P$ gene products. Thus, the additional haem-staining bands most probably correspond to FixO and FixP, but genetic characterization of $R$. leguminosarum bv. viciae fixO and fixP mutants will be required to confirm that the novel membrane-bound haem-stained proteins do indeed correspond to FixO and FixP.

\section{Absorption spectra of culture cells and bacteroids}

In an attempt to corroborate the haem stain and to identify a novel haem-containing terminal oxidase in bacteroids, we recorded absorbance difference spectra of intact cells and bacteroids, exploiting the photoreversible CO-binding properties of this class of cytochromes. The reduced minus oxidized difference spectrum of cultured cells of $R$. leguminosarum bv. viciae revealed an intense 


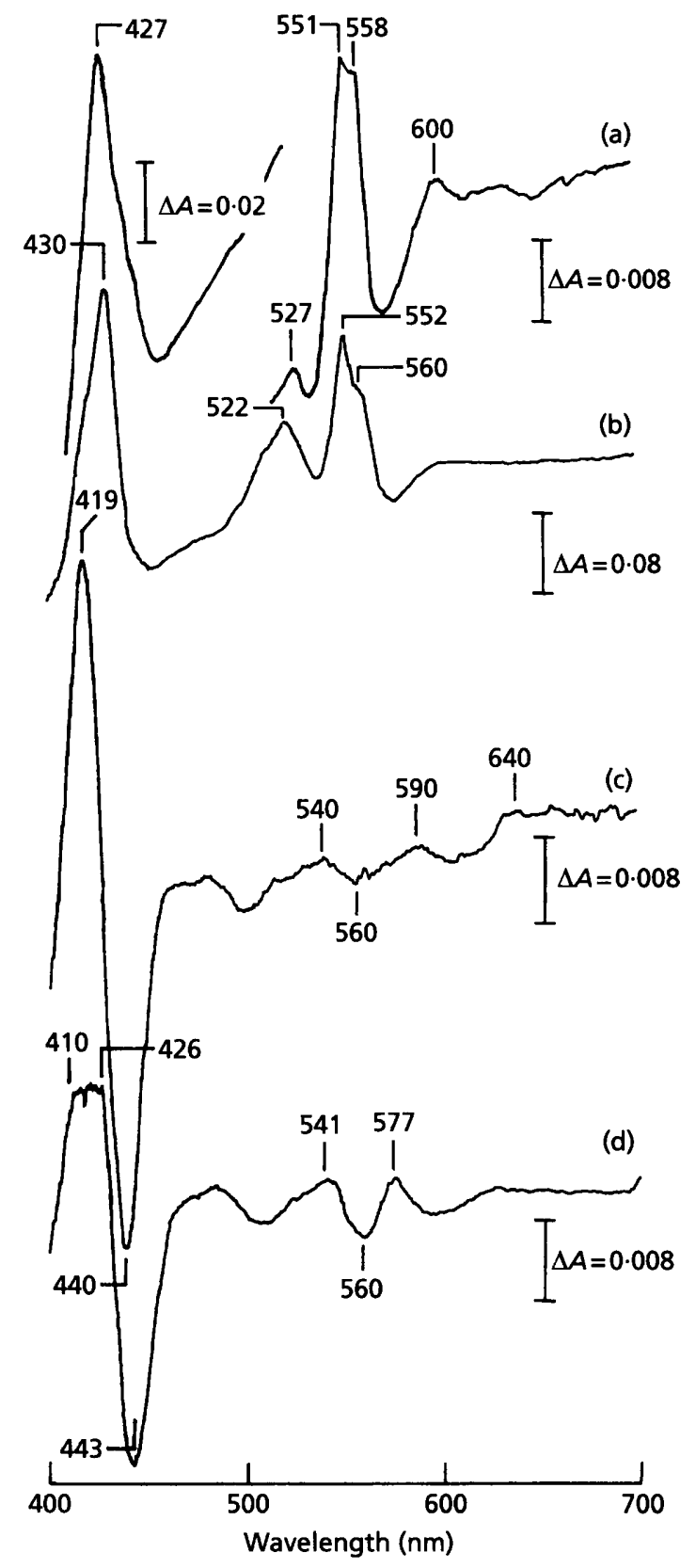

Fig. 3. Visible absorption difference spectra of $R$. leguminosarum cells and bacteroids. Spectra (a) and (c) were recorded using intact cells suspended at a final protein concentration of $7.2 \mathrm{mg} \mathrm{ml}^{-1}$. Spectra (b) and (d) were recorded using intact purified bacteroids suspended at a final protein concentration of $25 \mathrm{mg} \mathrm{ml}^{-1}$. Spectra (a) and (b) are reduced (dithionite) minus oxidized (persulphate) difference spectra at room temperature, whereas (c) and (d) are reduced (dithionite)plus-CO minus reduced difference spectra at room temperature. The pathlength was $10 \mathrm{~mm}$.

Soret band at $427 \mathrm{~nm}$ (Fig. 3a). The $\alpha$-peak at $551 \mathrm{~nm}$ is attributable to $c$-type cytochrome(s), the $558 \mathrm{~nm}$ shoulder to cytochrome(s) $b$ (Kretovich et al., 1973; Vargas et al., 1994) and the peak at $600 \mathrm{~nm}$ to cytochrome $a a_{3}$. A reduced minus oxidized spectrum of bacteroids from pea nodules (Fig. 3b) showed a Soret $(430 \mathrm{~nm}$ ) band similar to that of cultured cells, but the major $\alpha$-band was highly asymmetric. The $552 \mathrm{~nm}$ peak attributable to $c$-type cytochromes is significantly increased in intensity relative to that of the $560 \mathrm{~nm}$ shoulder attributable to cytochromes $b$. The increased level of cytochrome $c$ in bacteroids was also evident from the Soret and $\beta(522 \mathrm{~nm})$-bands, which showed significant asymmetry at shorter wavelengths. As noted by others (Kretovich et al., 1973), the absorption band at $600 \mathrm{~nm}$ due to cytochrome $a a_{3}$ was absent from bacteroids and the absence of a peak and trough at $630 \mathrm{~nm}$ and $650 \mathrm{~nm}$ indicates that cytochrome $d$ is also absent from bacteroids.

$\mathrm{CO}$ difference spectra were used to reveal putative terminal oxidases. The CO-reduced minus reduced difference spectrum of cultured cells (Fig. 3c) showed a distinct peak at $419 \mathrm{~nm}$ due to absorbance of the COcomplex of a haem protein. This peak and the corresponding trough at $440 \mathrm{~nm}$, due to loss of the ferrous form on CO binding, are at wavelengths too low to be attributed to cytochrome $a_{3}$ and arise from an additional component that is probably a ligand-binding, high-spin cytochrome $b$, or possibly $c$ (Poole, 1994; Wood, 1984). The presence of cytochrome $d$ in cultured cells (see below) suggests that this component is the high-spin cytochrome $b\left(b_{595}\right)$ associated with cytochrome $d$ in other bacteria (Poole, 1994). This component presumably masks the Soret absorbance band of cytochrome $a_{3}$ which is, however, detectable by the $590 \mathrm{~nm}$ peak. In contrast, the $\mathrm{CO}$ difference spectrum of intact bacteroids (Fig. 3d) showed a clear trough at $443 \mathrm{~nm}$. Although this is the position anticipated for unligated cytochrome $a_{3}$, the absence of the $\alpha$-band in Fig. 3(b) precludes this possibility. The trough is accompanied by a very broad Soret band centred at $420 \mathrm{~nm}$; the band shape clearly suggests the presence of at least two CO-binding components, probably with maxima near 410 and $426 \mathrm{~nm}$, respectively. At longer wavelengths, a broad trough centred at $560 \mathrm{~nm}$ and absorption maxima at 541 and $577 \mathrm{~nm}$ differed from the corresponding signals of cultured cells (Fig. 3c). The peak of absorbance at $640 \mathrm{~nm}$ in the cultured cells (Fig. $3 c)$ corresponds with the expected signal due to carbonmonoxy-cytochrome $d$, but this was not seen with bacteroids (Fig. 3d).

Such CO difference spectra reveal all CO-binding haem proteins, whether or not they have oxidase function. The majority of terminal oxidases can be identified more specifically in photodissociation spectra at low temperature, where the $\mathrm{CO}$ dissociated from the photolabile carbon-monoxy form, does not immediately rebind to the haem, allowing recording of the photodissociated (i.e. unligated) minus pre-photolysis difference spectrum. Such spectra are shown in Fig. 4(a-c). In the photodissociation spectrum of cultured cells reduced with dithionite (Fig. $4 a)$, the presence of cytochrome $a_{3}$ was confirmed by the appearance of the unligated reduced cytochrome at $446 \mathrm{~nm}$. In the corresponding spectrum of bacteroids (Fig. 4b), the Soret band was at a slightly lower wavelength $(443 \mathrm{~nm})$ and the corresponding trough was at $428 \mathrm{~nm}$. These spectral features closely resemble those of cytochrome $a_{3}$. However, the spectrum in Fig. 3(b) 


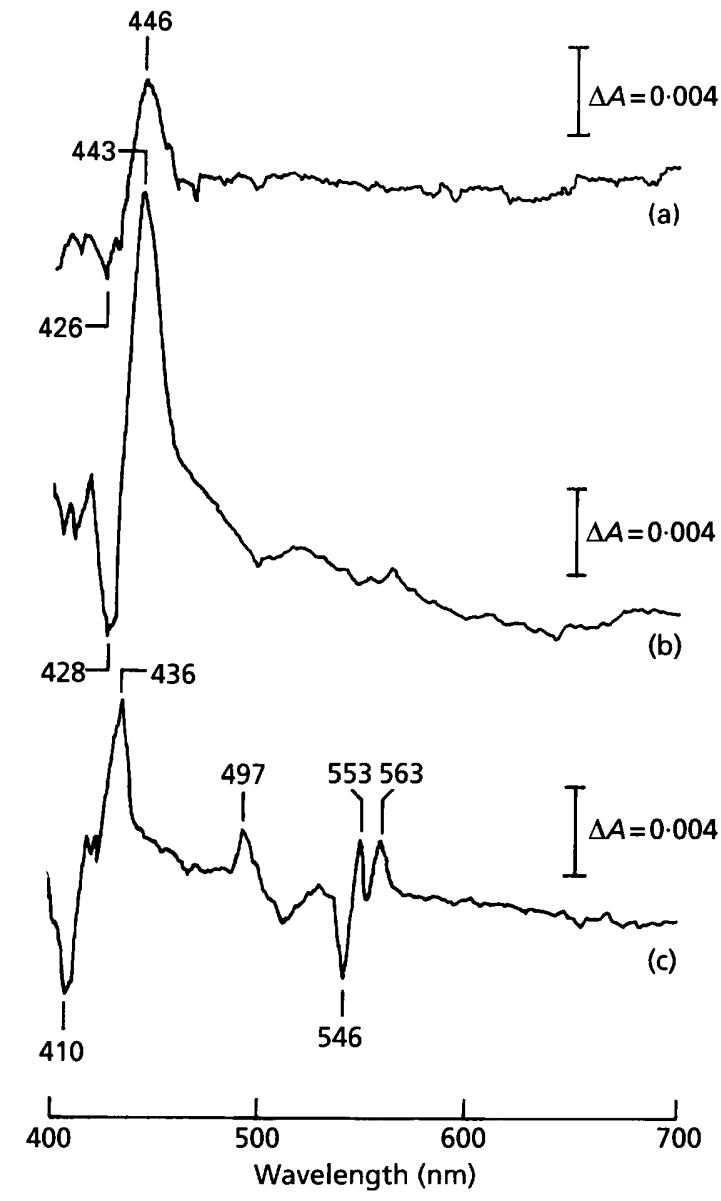

Fig. 4. Photodissociation spectra, i.e. photolysed minus prephotolysis, at $-100^{\circ} \mathrm{C}$. In each case, the spectrum is that obtained immediately after photolysis of the sample. Spectrum (a) shows cultured cells (protein concentration $5.0 \mathrm{mg} \mathrm{ml}^{-1}$ ) reduced with dithionite before bubbling with $\mathrm{CO}$, and $(\mathrm{b})$ is the corresponding spectrum for bacteroids (protein concentration $25 \mathrm{mg} \mathrm{ml}^{-1}$ ). In (c) the bacteroids were reduced with malate and succinate before bubbling with $\mathrm{CO}$. The pathlength was $2 \mathrm{~mm}$.

shows that cytochrome $a a_{3}$ is not present. The difference spectrum observed when bacteroids were reduced by endogenous respiration in the presence of succinate and malate (Fig. 4c) was clearly different from that obtained with dithionite in the absolute absence of oxygen (Fig. 4b). Fig. 4(c) shows that signals of narrow band width were observed in both Soret and $\beta / \alpha$-regions after photolysis, the pre-photolysis baseline being featureless (not shown). Peaks were observed at 436, 497, 553 and $563 \mathrm{~nm}$ and troughs were observed at 410 and $546 \mathrm{~nm}$. Re-scanning of the same sample after about 5 min revealed a shift of the Soret band to $431 \mathrm{~nm}$ (not shown). We consider that the most likely interpretation of these signals is that, in the absence of dithionite, residual oxygen in the sample reacts with the ligand-binding oxidase immediately after photolysis and before the scan shown in Fig. 4(c). This has been previously reported for the high oxygen affinity cytochrome $d$ of Escherichia coli (Poole et al., 1983). Thus, the difference spectrum recorded is oxygenated minus CO-reduced and the spectral features indicate that the two forms are distinct. In particular, for example, the oxygenated form absorbs more intensely at $436 \mathrm{~nm}$ than does the CO-ligated sample, whereas the converse is true at $410 \mathrm{~nm}$. As required by this interpretation the $410 \mathrm{~nm}$ trough attributed to loss of the CO-ligated oxidase (Fig. 4c) corresponds to the position of one of the components seen in the CO-plus-reduced minus reduced difference spectrum (Fig. 3d).

Further evidence that photolysis of the CO-ligated putative oxidase results in oxidation and turnover of respiratory chain components was obtained in an experiment in which oxygen was introduced into the substrate-reduced suspension at $-23^{\circ} \mathrm{C}$ before freezetrapping. This (Jones \& Poole, 1985; Poole et al., 1994) allows introduction of oxygen without displacement of $\mathrm{CO}$ until the sample is photolysed. The sample was scanned at $-110^{\circ} \mathrm{C}$, photolysed at $-110^{\circ} \mathrm{C}$, warmed to $-40{ }^{\circ} \mathrm{C}$ and then returned to $-110^{\circ} \mathrm{C}$ for recording difference spectra (post-photolysis minus pre-photolysis). (This procedure overcomes potential artefacts in difference spectra that compare spectra recorded at different temperatures.) The difference spectrum (not shown) revealed clear $\alpha / \beta$-troughs that indicated extensive cytochrome oxidation on raising the sample temperature. The $\alpha$-trough was at $550 \mathrm{~nm}$, with a shoulder at $560 \mathrm{~nm}$, and the $\beta$-trough was at $520-530 \mathrm{~nm}$, demonstrating the oxidation of both $c$ - and $b$-type cytochromes. In contrast, cytochromes $a_{3}$ and $o$ (Poole et al., 1994) react relatively slowly with oxygen after photolysis of the $\mathrm{CO}$ compound to form intermediate oxycompounds spectrally very similar to the CO-ligated forms.

These spectroscopic studies of bacteroids confirm the absence of cytochrome $a_{3}$ but confirm the presence of an unusual ligand-binding haemoprotein that appears to react with traces of oxygen at low temperatures. Such behaviour is consistent with the supposition that the bacteroid oxidase has a high affinity for oxygen.

There is clearly a strong induction of genes involved in $c$ type cytochrome formation in bacteroids and the unusual photodissociation spectrum may have revealed the new high affinity cytochrome oxidase in bacteroids. The fix $\mathrm{N}$ gene may encode such a high affinity oxidase, and photodissociation spectra measured using the purified oxidase will be required to confirm this. The bacteroidspecific components of the electron transfer chain appear to branch off from cytochrome $c_{1}$ since mutations in the gene encoding the cytochrome $c_{1}$ apoprotein completely block nitrogen fixation (Thöny-Meyer et al., 1989; our unpublished observations).

In parallel with the appearance of the bacteroid-specific cytochromes, the data presented clearly show that there is a repression of synthesis of cytochrome $a a_{3}$ and of a periplasmic cytochrome $c$. It will be of particular interest to determine if the fixL and fixK genes involved in activation of $f x N O Q P$ expression play any role in the repression of expression of cytochrome $a a_{3}$ and the periplasmic cytochrome $c$. 


\section{ACKNOWLEDGEMENTS}

We thank S. Rawsthorne for the gift of antiserum, N. J. Brewin for the gift of bacteroids and D. A. Hopwood for critical comments on the manuscript. This work was supported in part by an EU grant (CI1* CT90-0787) to J.A. D. and R. K.P. and by an EU fellowship (ERBCHBICT 930499) to M.-J. Delgado.

\section{REFERENCES}

Appleby, C. A. (1969a). Electron transport systems of Rbizobium japonicum. I. Haemoprotein P-450, other CO-reactive pigments, cytochromes and oxidases in bacteroids from $\mathrm{N}_{2}$-fixing root nodules. Biochim Biophys Acta 172, 71-87.

Appleby, C. A. (1969b). Electron transport systems of Rhizobium japonicum. II. Rhizobium haemoglobin, cytochromes and oxidases in free-living (cultured) cells. Biocbim Biophys Acta 172, 88-105.

Appleby, C. A. (1984). Leghemoglobin and Rhizobium respiration. Annu Rev Plant Pbysiol 35, 443-478.

Beynon, J. L., Beringer, J. E. \& Johnston, A. W. B. (1980). Plasmids and host range in Rbizobium leguminosarum and Rbizobium phaseoli. $J$ Gen Microbiol 120, 421-429.

Bott, M., Ritz, D. \& Hennecke, H. (1991). The Bradyrbizobium japonicum $c y c M$ gene encodes a membrane-anchored homolog of mitochondrial cytochrome $c$. J Bacteriol 173, 6766-6772.

Bradford, M. M. (1976). A rapid and sensitive method for the quantitation of microgram quantities of protein utilizing the principle of protein-dye binding. Anal Biochem 72, 248-254.

Bradley, D. J., Wood, E. A., Larkins, A. P., Galfrè, G., Butcher, G. W. \& Brewin, N. J. (1988). Isolation of monoclonal antibodies reacting with peribacteroid membranes and other components of pea root nodules containing Rhizobium leguminosarum. Planta 173, 149-160.

Brewin, N. J., Robertson, J. G., Wood, E. A., Wells, B., Larkins, A. P., Galfrè, G. \& Butcher, G. W. (1985). Monoclonal antibodies to antigens in the peribacteroid membrane from Rbizobium-induced root nodules of pea cross-react with plasma membrane and Golgi bodies. EMBO J 4, 605-611.

Downie, J. A., Hombrecher, G., Ma, Q.-S., Knight, C. D., Wells, B. \& Johnston, A. W. B. (1983). Cloned nodulation genes of Rhizobium leguminosarum determine host-range specificity. Mol \& Gen Genet 190 , 359-365.

Jones, C. W. \& Poole, R. K. (1985). The analysis of cytochromes Metbods Micrabiol 18, 285-328.

Kahn, D., Batut, J., Daveran, M. L. \& Fourment, J. (1993). Structure and regulation of the $f \times N O Q P$ operon from Rhizobium meliloti. In New Horizons in Nitrogen Fixation, p. 474. Edited by R. Palacios, J. Mora \& W. E. Newton. Dordrecht: Kluwer Academic Publishers.

Kretovich, W. L., Romanov, V. I. \& Korolyov, A. V. (1973). Rbizobium leguminosarum cytochromes (Vicia faba). Plant Soil 39, 619-634.
Mandon, K., Kaminski, P. A. \& Elmerich, C. (1994). Functional analysis of the $f \times N O Q P$ region of Azorbizobium caulinodans. $J$ Bacteriol 176, 2560-2568.

Poole, R. K. (1994). Oxygen reactions with bacterial oxidases and globins: binding, reduction and regulation. Antonie Leeuwenboek 65, 289-310.

Poole, R. K., Kumar, C., Salmon, I. \& Chance, B. (1983). The $650 \mathrm{~nm}$ chromophore in Escherichia coli is an 'oxy-' or oxygenated compound, not the oxidized form of cytochrome oxidase $d$ : an hypothesis. J Gen Microbiol 129, 1335-1344.

Poole, R. K., Salmon, I. \& Chance, B. (1994). The high-spin cytochrome $o^{\prime}$ component of the cytochrome bo-type quinol oxidase in membranes from Escherichia coli: formation of the primary oxygenated species at low temperatures is characterized by a slow 'on' rate and low dissociation constant. Microbiology 140, 1027-1034

Preisig, O., Anthamatten, D. \& Hennecke, H. (1993). Genes for a microaerobically induced oxidase complex in Bradyrbizobium japonicum are essential for a nitrogen-fixing endosymbiosis. Proc Natl Acad Sci US A 90, 3309-3313.

Schluter, A., Patschkowski, T., Weidner, S., Unden, G., Hynes, M. F. \& Priefer, U. B. (1993). Functional and regulatory characteristics of FnrN, an oxygen-responsive transcriptional activator in Rbizobium leguminosarum bv. viciae. In New Horizons in Nitrogen Fixation, p. 493. Edited by R. Palacios, J. Mora \& W. E. Newton. Dordrecht: Kluwer Academic Publishers.

Sherwood, M. T. (1970). Improved synthetic medium for the growth of Rbizobium. J Appl Bacteriol 33, 708-713.

Thöny-Meyer, L., Stax, D. \& Hennecke, H. (1989). An unusual gene cluster for the cytochrome $b c_{1}$ complex in Bradyrbizobium japonicum and its requirement for effective root nodule symbiosis. Cell 57, 683-697.

Turner, S. R., Ireland, R. \& Rawsthorne, S. (1992). Purification and primary amino acid sequence of the $\mathrm{L}$ subunit of glycine decarboxylase. J Biol Chem 267, 7745-7750.

Vargas, C., McEwan, A. G. \& Downie, J. A. (1993). Detection of $c$-type cytochromes using enhanced chemiluminescence. Anal Biochem 209, 323-326.

Vargas, C., Wu, G., Davies, A. E. \& Downie, J. A. (1994). Identification of a gene encoding a thioredoxin-like product necessary for cytochrome $c$ biosynthesis and symbiotic nitrogen fixation in Rhizobium leguminosarum. J Bacteriol 176, 4117-4123.

Williams, H. D. \& Poole, R. K. (1987). The cytochromes of Acetobacter pasteurianus NCIB 6428. Evidence of a role for a cytochrome $a_{1}$-like haemoprotein in electron transfer to cytochrome oxidase d. J Gen Microbiol 133, 2461-2472.

Wood, P. M. (1984). Bacterial proteins with CO-binding b- or c-type haem. Functions and absorption spectroscopy. Biochim Biophys Acta 768, 293-317.

Received 9 March 1995; revised 29 August 1995; accepted 6 September 1995. 